\title{
Violence and Justice in UNASUR's Institutional History. From the Early Optimism to the Fragile Cooperation Combating Criminality*
}

\author{
Marcos Alan S. V. Ferreira (Brazil)** \\ Rodrigo de Souza Framento (Brazil) ${ }^{* * *}$
}

\begin{abstract}
This paper aims to understand how the Union of South American Nations (UNASUR) has worked (or not) to promote policies to make progress in the fight against crime, criminal justice and citizen security in the period between 2012 and 2017. Although South America is regarded as a peaceful region by some researchers when it comes to interstate conflict, when looking at intrastate violence the region may be viewed as one of the most violent in the world. In this context, it is crucial to understand the role of regional organizations. Our work was grounded on the documental analysis of 34 minutes and official documents of the South American Council on Public Security, Justice and Coordination of Actions against Transnational Organized Crime (CSSCJDOT) of UNASUR. The results demonstrate that the CSSCJDOT was an innovation in bringing the debate of crime and violence to a regional organization, but its initial promises have not been fulfilled because of political changes in key member states, the excess of normativism in UNASUR and because of the crisis the organization currently undergoes.
\end{abstract}

\section{Keywords}

International Relations; Cooperation; Regionalism; Sovereignty; Violence; Organized Crime.

Reception Date: October 2018

Approval Date: March 2019

\footnotetext{
* This research was funded by Conselho Nacional de Desenvolvimento Científico e Tecnológico (CNPq), Programa de Bolsas de Iniciação Científica (PIBIC), and Programas Cátedras Escola Nacional de Administração Pública (ENAP), Edital 05/2018, Brazil. A previous version of this paper was presented in FLACSO-ISA Joint Conference 2018.

${ }^{* *}$ B. A. in Social Sciences. M. A. in International Relations. PhD in Political Science. Professor and researcher in Centro de Ciências Sociais Aplicadas, Universidade Federal da Paraíba, Brazil. E-mail: marcosferreira@ccsa.ufpb.br - Orcid: https://orcid.org/0000-0002-3196-6508

${ }^{* * *}$ B.A. in International Relations. Research Associate in the Center for Studies in Peace and Ethics in International Relations, Universidade Federal da Paraíba, Brazil. E-mail: rodrigoframento@, hotmail.com
} 


\section{How to Cite this Article}

Ferreira, Marcos Alan S. V. \& Framento, Rodrigo de Souza. (2019). Violence and Justice in UNASUR's Institutional History. From the Early Optimism to the Fragile Cooperation Combating Criminality. Estudios Políticos (Universidad de Antioquia), 55, pp. 87-110. http://doi.org/10.17533/udea.espo.n55a05

\section{Violencia y justicia en la historia institucional de Unasur. Desde el optimismo inicial hasta la frágil cooperación para combatir la criminalidad}

\section{Resumen}

Este artículo tiene como objetivo comprender cómo la Unión de Naciones Suramericanas (Unasur) ha estado trabajando para promover políticas que avancen en la lucha contra el crimen, la justicia penal y la seguridad ciudadana en el periodo 2012-2017. Aunque se considera que Sudamérica es pacífica según algunos investigadores, cuando se tiene en cuenta la violencia dentro del Estado la región puede considerarse una de las más violentas del mundo. En este contexto, es fundamental comprender el papel de las organizaciones regionales. Para este artículo se realizó un análisis de 34 documentos oficiales del Consejo Sudamericano de Seguridad Pública, Justicia y Coordinación de Acciones contra la Delincuencia Organizada Transnacional (CSSCJDOT) de Unasur. Los resultados demuestran que CSSCJDOT fue una innovación para llevar el debate del crimen y la violencia a una organización regional, pero sus promesas iniciales no se cumplieron debido a los cambios políticos en los Estados miembros clave, el exceso de normativismo en Unasur y la crisis que actualmente vive la organización.

\section{Palabras clave}

Relaciones Internacionales; Cooperación; Regionalismo; Soberanía; Violencia; Crimen Organizado. 
Violence and Justice in UNASUR's Institutional History. From the Early Optimism...

\section{Introduction}

Although South America is recognized as a zone of peace given the small number of interstate wars in recent history (Kacowicz, 1998; Holsti, 1996), the acute presence of crime in the region can be seen as one of its main problems. In this context, it is noteworthy that the main regional organization in South America in 2000s — Union of South American Nations (UNASUR) is pioneer in creating a council dedicated to create cooperative processes for promoting justice and fighting crime: The South American Council on Public Security, Justice and Coordination of Actions against Transnational Organized Crime (CSSCJDOT) (Ferreira, 2017a).

Given this scenario, the aim of this paper is to explore the initial cooperation processes created by the agency in South America, oriented by the following question: has CSSCJDOT been institutionalized as an effective regional forum to combat the endemic violence in South America? As it will be seen along the article, while violence is one of the main challenges to South American society, the CSSCJDOT unfortunately could not accomplish its goals. The ambition to create an effective cooperation was blocked by political changes in member states, as well as by an ambiguous approach by states regarding regional cooperation. At the same time, South American states try to create norms and regimes to regulate cooperation, but they are still attached to a traditional view on sovereignty.

Our historical analysis is based on qualitative research of official documents (minutes, reports and releases) of the CSSCJDOT, provided by the Digital Repository site of UNASUR. In the research we collected 43 documents provided by the platform or through direct contact with UNASUR secretaries from July 2012 through March 2017. Among these documents, we found 34 fit for our analysis based on our research question (see Table 1). The analysis of the material was made through a qualitative method of content analysis, based on the conceptual framework of Peace Studies.

This paper is divided into six parts. After this introduction, we explain the theoretical and contextual framework that underlies this research, as well as the main problems that affect peace in the region and the role of organizations such as UNASUR to mitigate these challenges. The following section examines the initial measures of the organization aimed at building its regulatory apparatus. Then, we describe the council's operations to create 
intentions, resolutions and joint and effective actions to deal with its three key themes (organized crime, justice and citizen security), as well as the board's division into three workgroups and their effectiveness. The fifth section shows the gradual weakening of the body, and finally the conclusions point out some elements that explain the lack of effectiveness of CSSCJDOT.

Table 1. UNASUR's Documents analyzed for this research.

$\square$ Cartagena. Resolución $N^{\circ}$ 19. (11 de junio de 2012). Consejo para fortalecer la cooperación en materia de seguridad ciudadana, de justicia y la coordinación de acciones contra la delincuencia organizada transnacional (CSSCJDOT).

Bogotá. Acta (27 de julio de 2012). । Reunión del grupo de trabajo del CSSCJDOT.

Bogotá. (2 de agosto de 2012). Informe ejecutivo de la I Reunión de trabajo del CSSCJDOT.

Lima. Acta. (6 de noviembre de 2012). II Reunión del grupo de trabajo del futuro CSSCJDOT.

Lima. Acta. (1 de marzo de 2013). I Reunión de la instancia ejecutiva del CSSCJDOT.

Lima. (1 de marzo de 2013). Informe ejecutivo de la I Reunión de la instancia ejecutiva del CSSCJDOT.

Lima. Acta. (10 de abril de 2013). ॥ Reunión de la instancia ejecutiva del CSSCJDOT.

Lima. Acta. (21 de mayo de 2013). III Reunión de la instancia ejecutiva del CSSCJDOT.

Lima. Acta. (14 de agosto de 2013). Iv Reunión de la instancia ejecutiva del CSSCJDOT.

Lima. Declaración Ministerial. (19 de agosto de 2013). I Reunión de ministros del CSSCJDOT de UNASUR.

Buenos Aires. Acta. (4 de octubre de 2013). Encuentro suramericano de ministros sobre lucha contra el lavado de activos -Fortaleciendo la cooperación de acciones contra el LA/FT-.

Buenos Aires. Compromiso de Buenos Aires. (4 de octubre de 2013). Encuentro suramericano de ministros para el fortalecimiento de la cooperación contra el lavado de activos y el financiamiento del terrorismo.

Buenos Aires. Acta. (19 de diciembre de 2013). । Reunión del grupo de trabajo de justicia CSSCJDOT.

Montevideo. Acta. (25 de febrero de 2014). I Reunión del grupo de trabajo en coordinación de acciones contra la delincuencia organizada transnacional del CSSCJDOT de UNASUR.

Montevideo. Acta. (13 de marzo de 2014). v Reunión de la instancia ejecutiva del CSSCJDOT.

Buenos Aires. Acta. (24 de abril de 2014). ॥ Reunión del grupo de trabajo de justicia CSSCJDOT. 
Table 1. (Continuation).

$\square$ Montevideo. Acta. (26 de junio de 2014). vı Reunión de la instancia ejecutiva del CSSCJDOT.

Montevideo. Acta. (27 de junio de 2014). ॥ Reunión de ministros del CSSCJDOT de la UNASUR.

$\square$ Quito. Acta. (9 de septiembre de 2014). III Reunión del grupo de trabajo especializado de justicia del CSSCJDOT.

Quito. Acta de Clausura. (12 de septiembre de 2014). Encuentro Regional "Gestión y Administración Penitenciaria en el contexto de Los Derechos humanos y la Seguridad Integral".

Montevideo. Acta. (30 de octubre de 2015). III Reunión de ministros del CSSCJDOT de la UNASUR.

Videoconferencia. Acta. (16 de mayo de 2016). I Reunión del grupo de trabajo de seguridad ciudadana.

Videoconferencia. Acta. (17 de mayo de 2016). I Reunión del grupo de trabajo de seguridad ciudadana.

Videoconferencia. Acta. (18 de mayo de 2016). I Reunión del grupo de coordinación de acciones contra la delincuencia organizada transnacional.

$\square$ Videoconferencia. Acta. (12 de julio de 2016). ॥ Reunión del grupo de trabajo de seguridad ciudadana.

Videoconferencia. Acta. (13 de julio de 2016). „ Reunión del grupo de trabajo de justicia.

Videoconferencia. Acta. (15 de julio de 2016). ॥ Reunión del grupo de coordinación de acciones contra la delincuencia organizada transnacional.

Videoconferencia. Acta. (24 de agosto de 2016). III Reunión del grupo de trabajo de justicia.

Videoconferencia. Acta. (29 de agosto de 2016). III Reunión del grupo de trabajo de seguridad ciudadana.

Videoconferencia. Acta. (30 de agosto de 2016). III Reunión del grupo de coordinación de acciones contra la delincuencia organizada transnacional.

$\square$ Caracas. Acta. (25 de noviembre de 2016). Ix Reunión de la instancia ejecutiva del CSSCJDOT.

Caracas. Acta. (28 de marzo de 2017). xı Reunión de la instancia ejecutiva del CSSCJDOT de UNASUR.

Caracas. Acta. (29 de marzo de 2017). Iv Reunión de ministros del CSSCJDOT de UNASUR.

Caracas. Declaración Ministerial. (29 de marzo de 2017). ıv Reunión de ministros del CSSCJDOT de UNASUR.

Source: Collected from UNASUR (n.d.). 


\section{The South American Paradox: A Zone of Interstate Peace without Domestic Peace}

The conceptual development provided by the Peace Studies may be seen as key to grasp contexts of organized crime and violence, as is the case in South America. This has been previously explained by Ferreira (2017b). Furthermore, in the article "Violence, Peace and Peace Research," Johan Galtung (1969) brings a seminal contribution to thinking about violence and peace in broader terms than the simple absence of war.

For Galtung (1969), violence should be divided into three: direct, structural and cultural. Direct violence takes place when there is a person who commits the violent act, whether injury or death, and may use a weapon or not. This violence may be exerted on yourself or on a third party. Structural violence is a socioeconomic setting characterized by the denial of access to scientific and social developments, resulting in lower life expectancy, unemployment, deaths caused by curable diseases and inequality. This means that inequality is structural violence because it makes many people unable to achieve the same quality of life than their wealthier counterparts (Galtung, 1969).

Additionally, Galtung describes a third form in which violence may be expressed besides direct and structural. Cultural violence consists of constructed symbols seeking to differentiate between what is right and what is wrong. It does not kill or hurt by itself, but it serves as a tool to legitimize the use of structural and direct violence. Thus, racism, sexism, superstition, religious fundamentalism and nationalism serve to divide people according to a binary relationship of right and wrong which ultimately legitimizes structural and direct violence (Galtung, 1990; Oliveira, 2017).

In this regard, the Peace Studies break with the classic defense and security studies that define peace as the absence of war. The understanding of peace as the absence of violence entails a greater number of variables to consider its existence, such variables include not only the end of a conflict (negative peace), but also the end of a number of structural and direct violence within society (positive peace). Therefore, peace must be built beyond the level of interstate relations.

This broadening of the concepts of violence and peace is pertinent to reflect on the changes that are being promoted on the international relations 
in the post-Cold War era. Banfield (2014) states that, for the first decade of the new millennium, the greatest threats to international security are the actions of organized crime and extremist movements.

In this context, South America represents one of the regions where violence problems within the Galtungian framework can be more clearly noticed. The low incidence of armed conflicts between the nations in the region suggests that it is peaceful. ${ }^{1}$ However, the region is world leader in firearm homicides and it is third among the highest homicide rates-only surpassed by Sub-Saharan Africa and Central America, according to United Nations Office on Drugs and Crime (Ferreira, 2017b). Thus, although the region has not suffered a major war for more than a century, it has also not experienced a context of peace (Villa \& Pimenta, 2016). Lastly, the conceptual framework offered by the Peace Studies helps us understand adequately the problems that the region lives (Ferreira, 2017a).

Transnational organized crime (TOC) is the main manifestation of this violence. It occurs within the unequal social context, generating profits for the illicit market and promoting harm (violence) in a society characterized by a weak state apparatus (Cepik \& Borba, 2011; Werner, 2009). Specifically, TOC thrives in a context permeated by social tensions caused by structural and cultural violence expressed against minorities such as black and indigenous peoples, as well as peasants. Thus, organized crime uses structural and cultural violence, affecting these strata of society to reproduce the same violent structure. In other words, crime is an agent resulting from structural violence just as it is a structured agent causing that same structural violence (Ferreira, 2017b).

Such a context of high violence becomes even more remarkable when we look at a second catalyst element of organized crime: the globalization of markets and communications. The end of the socialist socioeconomic project has led to increased flows of goods and people, and consequently of criminal groups dealing drugs, arms and human beings (Ferreira, 2017a; Zabyelina, 2009). Technological innovations since the 1990s, especially in transport and communications, have also been important for the expansion of organized crime. Lastly, the global trend toward the adoption of commercial and financial liberalism, breaking many state barriers to the movement of

${ }^{1}$ The latest conflict registered was between Peru and Ecuador in 1995, they fought to reset a part of the border between the two countries. 
goods and capital, is being a key asset for organized crime to move their illegal profits (Cepik \& Borba, 2011; Zabyelina, 2009).

In South America, illicit drugs are the most important commodities of organized crime and cocaine emerges as the primary product. Fragile states are important hotspots in the narcotics trafficking since they have porous borders and poorly paid officials and because of the public indifference or consent, all of which strengthen criminal enterprises. In addition to the great movement of capital, the TOC is also responsible for most of the violent murders, mainly for resolving business disputes and discouraging competition (Banfield, 2014).

As seen in large Latin American cities, the urban environment is the primary location where violence and organized crime relate. The stratification and inequality in cities serve as a major catalyst for these violent acts, being the formation of gangs an example of this phenomenon (Banfield, 2014). Inequality and exclusion associated with the unequal distribution of economic, social and political resources in urban contexts — such as income, employment, education, health and infrastructure - intersect with poverty to generate a prolific context for the emergence of violence. In addition, the failure of security and policing, as well as poor access to justice, affect

[ 94 ] particularly the underprivileged, who are unable to pay for their own services and thus are more susceptible to impunity (Imbusch, Misse \& Carrión, 2011).

It is also important to notice that violence in many cities of South America can be compared to the numbers of death in conflict zones, as can be exemplified by the Brazilian case. For example, the total number of murders in Brazil in just three weeks exceeds the number of deaths due to all terrorist attacks worldwide in the first five months of 2017 (Cerqueira et al., 2017). Furthermore, according to the Mexican NGO Seguridad, Justicia y Paz (2017), based on 2016 homicide rates and taking into account cities with at least 300,000 inhabitants, 24 of the 50 cities with the highest violence rates are in South America.

The state is also seen as one key agent promoting violence in the region. Violent actions by the police forces are common in battles against drug traffickers in poor communities and even against peaceful protests (Imbusch, Misse \& Carrión, 2011). The lack of opportunities and the profound inequalities, as well as a violent culture and the absence of confidence in the state as a promoter of peace, set up a perfect scenario for the development and strengthening of TOC (Ferreira, 2017a). 
Faced with a problem that goes beyond borders like organized crime, it is essential to understand the cooperative actions promoted by regional organizations (Kim, 2016, pp. 26). On this issue, for Brazil and its neighbor countries, UNASUR (Union of South American Nations) stands out as a regional forum. We started our research from the assumption that in the case of South America, UNASUR can have a central role in fighting crime. Created in 2008, the organization is the direct result of the redefinition of regional policies in South America, seeking the exclusion of US proposals and inclining to a greater autonomy in the policymaking of the subcontinent (Sanahuja, 2012; Ferreira, 2017a).

Based on these features, the South American Council on Public Security, Justice and Coordination of Actions against Transnational Organized Crime (CSSCJDOT) was created in 2012 in order to act as a "body for consultation, coordination and cooperation" among South American countries in matters related to security and justice, as well as to execute actions against transnational organized crime (TOC). The CSSCJDOT was born from the UNASUR discussions on other council, the World Drug Problem Council (CSPMD) in an attempt not to associate the security strategies and combating drug trafficking. Its creation is a recognition that threats to security in the region are not conventional threats from state conflict, but from deeper problems related to social inequality and state fragilities (Lyra, 2014; Ferreira, 2017a), which deserve the discussion of cooperative policies to promote less violent social environments. ${ }^{2}$ From the beginning, this forum proved to be quite innovative as it seeks to address an important social issue in an endogenous and autonomous way.

Today, UNASUR experiences a serious crisis related to political differences between left and right wing governments in the region, especially after the rise of presidents Mauricio Macri in Argentina, Lenín Moreno in Ecuador, Ivan Duque in Colombia and Jair Bolsonaro in Brazil. Nevertheless, as it will be seen in the following sections, significant developments to deal with violence were created by UNASUR. This article shows that some of these advancements bring responses for common problems, in which the ideological deadlock acts as an obstacle to decreasing regional violence.

\footnotetext{
${ }^{2}$ The authors are aware that a review of a Council of UNASUR could be done through the theoretical lenses of international regimes, international organizations and/or governance. Nevertheless, since we do not have yet a regime on the issue of TOC and UNASUR is still at risk, our paper seeks to assess how CSSCJDOT responds to the context of violence in the region instead. In other words, the focus here is to examine the potential of CSSCJDOT in a scenario of endemic violence, even if it lacks the adequate institutionalization.
} 


\section{The Initial Discussions and Institutionalization of $\mathrm{CSSCJDOT}^{3}$}

Since the early years, organized crime was present in the discussions at UNASUR. This can be seen with the creation of the World Drug Problem Council (CSPMD) in 2009 in order to address the drug problem beyond a prohibitionist policy in current international regimes. Nevertheless, it was noted that dealing only with the issue of drugs is inadequate because TOC and criminal justice in the region are more complex problems (Framento \& Ferreira, 2018). Consequently, in a meeting in Cartagena, Colombia, the Ministers of Defense, Justice, Security, Interior and Foreign Affairs of the 12 member countries of UNASUR, decided on May 2012 to recommend the creation of an independent body to coordinate the fight against organized crime and to promote justice and citizen security in the region in cooperation with the CSPMD.

The creation of a council concentrated on the issue of TOC is a clear recognition that this phenomenon challenges the capacity of the state to control its borders. Moreover, efforts to combat TOC also require coordination of the countries to share experiences and information and to execute joint actions.

[ 96 ] Thus, the creation of the council brought expectation on a new approach to fighting crime and advancing criminal justice, overcoming a view of criminality and justice as internal problems of each country.

In July 2012 a meeting to prepare the statute of CSSCJDOT took place, the objective was to define the nature, principles and general goals. The countries also agreed to create an action plan for the Council and proposed a comparative study to establish coordination with the CSPMD, commissioned by the General Secretariat ${ }^{4}$ (Framento \& Ferreira, 2018).

At the second meeting in Lima (Peru), held in November 2012, progress was made with the proposed coordination between the CSPMD and CSSCJDOT using the statute of CSPMD as a basis. Articles that could generate coordination areas were identified, such as judicial and police cooperation in the training of professionals, legal cooperation and security coordination for the reduction of drug supply, as well as control measures against money

\footnotetext{
${ }^{3}$ A more detailed overview about the creation of CSSCJDOT can be found in Framento \& Ferreira (2018).

${ }^{4}$ Bogotá. (2 de agosto de 2012). Informe ejecutivo de la I Reunión de trabajo del CSSCJDOT.
} 
laundering. Another recommendation was that the statute of CSSCJDOT could provide the objectives of the coordination of actions with the CSPMD (Framento \& Ferreira, 2018).

The meeting was also important to approve the statute of the Council, whose nature is reported as a permanent body of consultation, coordination and cooperation between Member States to combat TOC and for the promotion of justice and public security. These principles are in accordance with the constituent treaty of UNASUR and the UN Charter; unrestricted respect for sovereignty, self-determination, human rights and fundamental freedoms of citizens. Also among the principles are the promotion of social inclusion, civic participation and gender equality (Terra, 2012, maio 4). At that time general and specific objectives of the organization were established as well. This can be seen in Table 2.

Table 2. General and Specific Objectives CSSCJDOT.

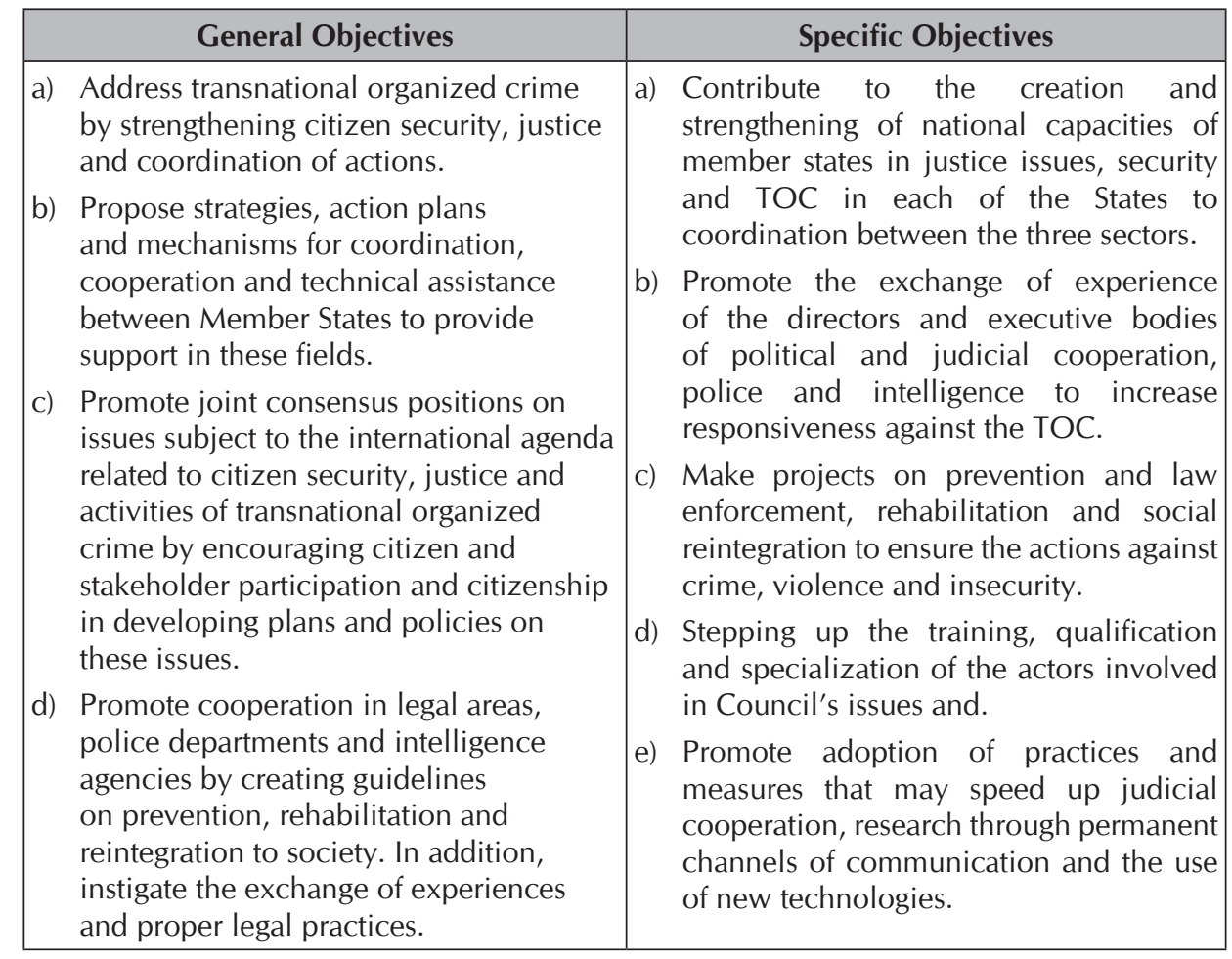

Source: Collected from Framento \& Ferreira (2018). 
Some contradictions can be noticed since the beginning of the CSSCJDOT institutionalization. For example, in one of its articles respect for the right of each state to identify their priorities concerning the actions on citizen security, justice and action against the TOC is demonstrated. However, the next article asks for full coordination in the planning and execution of actions against TOC. Moreover, the extensiveness of the principles and the indication of unlimited respect for sovereignty are issues that make us question the actual effectiveness of a cooperation body without mandatory settlements. About this contradiction, Sanahuja (2012) states that South America is facing a "trilemma" standing in the middle of the respect for the defense of sovereignty, the desire for an effective regional integration, and the search for autonomy internationally; impossible to be resolved simultaneously (Framento \& Ferreira, 2018). This is clearly seen in the current UNASUR crisis, as mentioned before (Vitelli \& Souza, 2018, maio 21).

This situation comes from the fact that the region has created UNASUR seeking autonomy from USA, with the desire to provide efficient mechanisms for defining policies themselves in this instance. Nonetheless, this desire, at least on the Council, is in fact challenged by the avoidance of compromising national sovereignty with supranational policies (Framento \& Ferreira, 2018).

[ 98 ] The region keeps a historical tradition of a static conception of sovereignty that does not give room for supranational cooperation (Legler, 2013). In this sense, the real possibility of diffusion policies can be questioned, even more in the current serious crisis of the UNASUR. ${ }^{5}$

After the adoption of the Statute of the CSSCJDOT, the discussion on the adoption of an Action Plan was open. Under the leadership of Argentina, the CSSCJDOT reached the consensus on applying the methodology of defining themes, strategic challenges and lines of action for each area of the Council, a structure that was kept in final text. Given the size of the Action Plan, it was considered that the best option was to treat it at the moment of setting

\footnotetext{
${ }^{5}$ The decisions have not been approved by consensus since 2017, when the Ambassador Jose Octavio Bordon was appointed General Secretary by Argentina according to the structure of UNASUR. The impasse led to the voluntary suspension of six members of the organization: Argentina, Brazil, Chile, Colombia, Paraguay and Peru. The communication of the suspension was made official by the six countries through a formal letter after the Minister of Foreign Affairs of Bolivia, Fernando Huanacuni, became the pro-tempore president of the organization on April 20, 2018. The bloc called for his removal with the intention of pressuring the organization to appoint a permanent Secretary General for Argentina. For more on the crisis of UNASUR, especially after 2018, see Vitelli \& Souza (2018, maio 21), and Ferreira (2018, junho 20).
} 
each one of the Working Groups. A plan of action was proposed to combat a topic of interest to both the justice system and security of the region —human trafficking - to be supported by the Common Initiatives Fund of UNASUR. This project would be accomplished with the "South American campaign of sensitization and awareness on the theme of Human Trafficking" led by Argentina, ${ }^{6}$ although Brazil has tried through the Ministry of Justice promote this regional debate since 2010 (Framento \& Ferreira, 2018; Ministério da Justiça, 2010).

The Ecuadorian delegation presented, between 28 February and 1 March 2013, a proposal to create a UNASUR Criminal Court against TOC. The court should not override the Inter-American Court of Human Rights, since the trial of offenses liabilities would be drug trafficking, trafficking in persons and organs, money laundering, corruption, cybercrime, trafficking in cultural goods, and other transnational crimes. However, the Ecuadorian delegation eventually withdrew the proposal, considering that an action of this magnitude could only be carried out after consolidating the CSSCJDOT.? Nevertheless, civil society continues to have this issue on its agenda through COPLA (Latin-American and Caribbean Coalition for the Criminal Court against TOC), based in Buenos Aires. COPLA currently has the support of 25 other NGOs and foundations, as well as parliamentarians and academics from several Latin American countries (Framento \& Ferreira, 2018).

Another relevant proposal in the early stages was the "South American Network Against Transnational Organized Crime," also an Ecuadorian proposal. The exchange of operational information is proposed for the development of intelligence activities with the support of UNASUR and alliances with organizations such as INTERPOL ${ }^{8}$ (Framento \& Ferreira, 2018).

The first meeting of ministers of the CSSCJDOT marks the end of the first steps in the institutionalization of this council. In a meeting held in Lima, Peru, on August 19, 2013, the Ministers stated that the TOC is a regional challenge and should be tackled jointly. Moreover, in the meeting the Action Plan for 2013-2017 was approved, encompassing 11 themes, 30 strategic

\footnotetext{
${ }^{6}$ Lima. Acta. (21 de mayo de 2013). III Reunión de la instancia ejecutiva del CSSCJDOT.

${ }^{7}$ Lima. Acta. (21 de mayo de 2013).

${ }^{8}$ The International Criminal Police Organization is responsible of sharing criminal intelligence and joint activities among its 190 Member States.
} 
challenges and 137 lines of action divided into three themes of the Council (TOC, Citizen Security and Justice).

\section{CSSCJDOT Looking for an Effective Regional Role}

After the consolidation of the Council and its Action Plan, the board entered into a new phase of more actively promoting joint cooperation policies. The milestone of this change was the South American Meeting of Ministers "Strengthening Cooperation Measures Against Money Laundering (ML) and Terrorist Financing (TF)" held on October 4, 2013 in Buenos Aires, Argentina. This meeting had the participation of Argentina, Bolivia, Brazil, Chile, Ecuador, Paraguay, Peru, Uruguay and Venezuela. Additionally, to reaffirm the willingness of ministers to produce practical results of rapid implementation, the "Buenos Aires Commitment" was signed.

The commitment believes that the $\mathrm{ML} / \mathrm{TF}$ offenses pose a direct threat to the security of the states and threaten the functioning of democratic institutions, producing distortions in regional economies by undermining the development initiatives and social equality. Thus, countries have agreed to exchange information and experiences, to conduct an analysis of tools and

[100] actions promoted at the regional and national levels to combat ML and TF, and to promote security measures for employees in finance institutions to investigate irregular operations.

Another important development was the approval of the division of the Council into three Working Groups (WG) — citizen security, justice and TOC - to facilitate the decision-making process. The WGs actions require the participation and contact of experts in the areas from each country. Given this, the formation of these groups also creates a higher expectation about the effectiveness of the actions of the Council.

During this period, the strong involvement of Argentina is clearly seen, which led about $40 \%$ of all actions planned by the three Working Groups alone (see Table 3). Countries like Brazil and Venezuela, major supporters of UNASUR in 2008, have little significant participations. It can be assumed that the death of Hugo Chavez in March 2013 has affected the leadership of his country as a major driver of Latin American integration. Additionally, the economic difficulties Venezuela experiences since 2013 with the drop of oil prices is another factor that may explain the decline of the participation of the country. 
Table 3. Major Meetings and Seminars Promoted by CSSCJDOT according to their Action Plan.

\begin{tabular}{|c|c|c|c|}
\hline Meeting & Date & City & Goals / Results \\
\hline $\begin{array}{l}\text { South American } \\
\text { Meeting of Ministers } \\
\text { About the Fight } \\
\text { Against Money } \\
\text { Laundering (ML) and } \\
\text { Terrorist Financing } \\
\text { (TF) }\end{array}$ & October 2013 & $\begin{array}{l}\text { Buenos } \\
\text { Aires }\end{array}$ & $\begin{array}{l}\text { It was considered that the offenses } \mathrm{ML} \\
\text { / TF represent a direct threat to the } \\
\text { security and functioning of democratic } \\
\text { institutions. The countries agreed to } \\
\text { exchange information, conduct an } \\
\text { analysis of tools and actions promoted } \\
\text { at regional and national levels to combat } \\
\text { ML and TF. }\end{array}$ \\
\hline $\begin{array}{l}\text { Regional Meeting for } \\
\text { the Exchange of Good } \\
\text { Practices in the Area } \\
\text { of Access to Justice }\end{array}$ & March 2014 & $\begin{array}{l}\text { Buenos } \\
\text { Aires }\end{array}$ & $\begin{array}{l}\text { Dealing with regional experiences in } \\
\text { access to justice and social inclusion } \\
\text { policy; alternative methods of conflict } \\
\text { resolution; the state as a guarantee of } \\
\text { access to legal information; integration } \\
\text { and citizenship rights of immigrants; } \\
\text { access to justice for persons with } \\
\text { disabilities, etc. }\end{array}$ \\
\hline $\begin{array}{l}\text { Security Policy } \\
\text { Seminar for Social } \\
\text { Inclusion }\end{array}$ & August 2014 & $\begin{array}{l}\text { Buenos } \\
\text { Aires, } \\
\text { Argentina }\end{array}$ & $\begin{array}{l}\text { Exchange of knowledge and successful } \\
\text { experiences in social prevention of } \\
\text { violence and social policies aimed at } \\
\text { inclusion (Ministerio de Seguridad, } \\
\text { 2014, agosto 22). }\end{array}$ \\
\hline $\begin{array}{l}\text { Regional Meeting } \\
\text { on the Public Policy } \\
\text { Development with } \\
\text { Citizen Security } \\
\text { Perspective on } \\
\text { Human Rights }\end{array}$ & August 2014 & $\begin{array}{l}\text { Caracas, } \\
\text { Venezuela }\end{array}$ & $\begin{array}{l}\text { The event was to order the exchange } \\
\text { of public policy experiences of the } \\
\text { participating nations in order to } \\
\text { strengthen the activities of States on this } \\
\text { issue, respecting human rights. }\end{array}$ \\
\hline $\begin{array}{l}\text { Regional workshop } \\
\text { for the prevention } \\
\text { and comprehensive } \\
\text { action against human } \\
\text { trafficking }\end{array}$ & March 2015 & $\begin{array}{l}\text { Buenos } \\
\text { Aires, } \\
\text { Argentina }\end{array}$ & $\begin{array}{l}\text { Foster the exchange of experiences } \\
\text { and identify the actions linked to better } \\
\text { police research practices and successful } \\
\text { interventions against trafficking in } \\
\text { persons and assistance to victims of } \\
\text { sexual and labor exploitation (Ministerio } \\
\text { de Seguridad, 2015, abril 27). }\end{array}$ \\
\hline $\begin{array}{l}\text { Regional Meeting } \\
\text { on Arms Control } \\
\text { Fire and Civil Use of } \\
\text { Explosives }\end{array}$ & June 2015 & Lima, Peru & $\begin{array}{l}\text { There was participation of the Small } \\
\text { Arms Survey (Switzerland), Teaching } \\
\text { Institute for Sustainable Development } \\
\text { (Guatemala), United Nations Office } \\
\text { on Drugs and Crime and UNLIREC } \\
\text { (United Nations Regional Center for } \\
\text { Peace, Disarmament and Development } \\
\text { in Latin America and the Caribbean) } \\
\text { who analyzed the global trends and } \\
\text { armaments control policies. }\end{array}$ \\
\hline
\end{tabular}

Source: Collected from UNASUR documents (see Table 1). 
About the low level of participation of the Brazilian government, the post-Lula period was followed by great difficulties in the country, and the favorable international scenario for Brazilian diplomatic performance collapsed. The end of the economic expansion period as a result of the global financial crisis, the economic problems the country still faces in its domestic context and the competition of the Chinese development model, led to the weakening of the Brazilian industrial exports (Malamud, 2017). On the domestic front, the country experienced a political crisis since the presidential elections of 2014 that were contested by the losing candidate, Aécio Neves. The country experienced since then a deep governability crisis that lead to the impeachment of President Dilma Rousseff. Finally, the election in 2018 of the far-right candidate, Jair Bolsonaro, made the dialogue in regional organizations almost impossible because of his tendency toward aligning with Donald Trump's administration in the United States. Together, these factors have caused a low participation of the country in general discussions of UNASUR during this period, with the exception of the South American Defense Council, considered the main forum in the organization.

The internal situation of these countries, the two largest supporters of UNASUR, eventually reflected on their financial participation in the organization. According to the Annual Budget Law 2012, Brazil approved $\mathrm{R} \$ 3,957,831.00$ for UNASUR, it went up in 2014, to $\mathrm{R} \$ 7,194,040.00$ and suffered an abrupt drop in 2016, with only $\mathrm{R} \$ 1,000,001.00$-the last data available. ${ }^{9}$

In this context of political and economic weakness in the countries that led the early years of UNASUR, an open space was filled by Argentina. The country sought its own leadership focused on the separation of defenseled by Brazil in the CDS-and security issues, which have a clear division in Argentina. This topic is related to the political history of the country, where there is a strong belief that the armed forces cannot be involved in internal security issues..$^{10}$ Thus, this leadership is related to internal political beliefs coupled with ambitions of regional power projection in subjects marginalized by other leaders like Brazil.

\footnotetext{
${ }^{9}$ Brasil. Congresso. Câmara dos Deputados. Lei 12595. (19 de janeiro de 2012); Lei 12952. (20 de janeiro de 2014); Lei 13255. (14 de janeiro de 2016).

${ }^{10}$ We thank here the comments of the Dr. Carolina Sampo (CONICET, Argentina).
} 
In the following months, the progress of the proposals in CSSCJDOT slowed down, mainly because of the lack of commitment by some member countries. For example, regarding the recollection of data that are key for policy formulations, in the April 2014 meeting of the Justice WG, ${ }^{11}$ the presidency (Argentina) mentioned the absence of answers from Chile and Bolivia to the booklet of good practices in rehabilitation of persons deprived of liberty and prison management policies.

Another example of lack of commitment was the questionnaire about the experience on organization and systematization of legal information that could be critical to the advancement of cooperation in intelligence matters and to the legal harmonization in the fight against organized crime. The Presidency reported that only seven states sent responses to systematize information and present a concrete proposal on this point to the executive body. Even with all the difficulties, Argentina published the discussions after the Regional Meeting for Exchange of Good Practices in the Area of Access to Justice, held in Buenos Aires in March 2014.The document comprises seven chapters, dealing with regional experiences on issues such as access to justice, alternative methods of conflict resolution as a guarantee of access to justice for minorities and vulnerable groups. Thus, Argentina attended five of the actions planned in the justice Working Group schedule (50\% of what was projected in the Action Plan), reinforcing its leadership in beneficial processes in the CSSCJDOT, even with all difficulties presented..$^{12}$ In the VI Meeting of the Executive Body (June 2014), three previous meetings of the Citizen Security WG via videoconference were reported. In these previous meetings the decision was made to carry out a commitment on the promotion, development and support of public policies for citizen participation in security, as well as the project on the development of public policies on citizen security with perspective on Human Rights, in addition to the awareness campaign about the risks of the use of firearms by civil society. It was only at the Third Meeting of Ministers of Public Safety, Justice and Transnational Organized Crime, held in Montevideo on October 30, 2015, that relevant resolutions can be noticed, although they do not advance adequately yet. The creation of UNASUR's Network Against

\footnotetext{
${ }^{11}$ Buenos Aires. Acta. (24 de abril de 2014). II Reunión del grupo de trabajo de justicia CSSCJDOT.

${ }^{12}$ The same happened in the Justice WG. The Regional Meeting on Management and Prison Administration, in the charge of Ecuador, discussed the prison systems and the successful experiences of prison management and social reintegration of persons deprived of liberty.
} 
Transnational Organized Crime was suggested and the UNASUR's Document on Minimum Rules on Access Justice was subscribed, recognizing the role of the State in promoting access to justice and eliminating inequalities. Peru proposed the creation of a Center for Strategic Studies against Transnational Organized Crime (CECOT) in order to identify its factors and causes, as well as to analyze the challenges of the region using methods and empirical evidence. Moreover, a proposal by the General Secretary to coordinate with European Union funding projects for state enforcement via EUROSocial ${ }^{13}$ was also signed. Nevertheless, nothing has been found to show the effectiveness of these actions, which makes us believe that the CSSCJDOT is below the actual need for response to the violence in South America.

\section{The Gradual Weakening of the CSSCJDOT}

Over the years, some difficulties to advance the CSSCJDOT have become clearer. This is evident, for example, in the failure of the Regional System for Living Indicators and Public Safety and also in the information exchange, both suffering the lack of commitment by states. ${ }^{14}$ The difficulty in obtaining information from member states was constant throughout the operations of the council, this situation shows little interest or security concerns about the

[104] release of this kind of data. One of the reasons for this may be the adherence to a classical model of sovereignty, which prefers to treat this data nationally. Sensitive data are not shared for the joint action of States, weakening the CSSCJDOT ambitions (Legler 2013; Ferreira, 2017a).

One of the few actions implemented was the International Course on the Progressive and Distinctive Use of Police Force under the tutelage of Venezuela and Ecuador. It was attended by representatives of the National Police of Ecuador, officials of the National Armed Forces of Venezuela, Bolivarian Army and Police National Tactical Forces. Organized by the National University on Experimental Security (UNES, Venezuela), the focus was the differentiated use of force with an emphasis on the respect of human rights and the care for the physical integrity.

\footnotetext{
${ }^{13}$ EUROsocial is a European Commission program of cooperation between Europe and Latin America, which seeks the institutional strengthening of the countries in the region through assistance in institutional design, reform and implementation of public policies

${ }^{14}$ Caracas. Acta. (25 de noviembre de 2016). Ix Reunión de la instancia ejecutiva del CSSCJDOT.
} 
Another action detailed in the documents is the advancement of UNASUR's Network Against TOC. In 2015, the pro-tempore presidency issued a detailed summary of the current status of the creation of the network and approved its creation in the Meeting of Council of Ministers of Foreign Affairs in Caracas, Venezuela, held in November, 2016. The ministers agreed to designate a representative for the Network for each Member State within 30 days. $^{15}$ As of January 2018, the coordinators were not disclosed, and we could not find records on the creation of the network in the UNASUR website, nor from the funding of the UNASUR Common Initiatives Fund.

In the WGs, no significant advancements were made. At the WG on TOC, delegations have also postponed several actions. Not even a simple questionnaire on national anti-trafficking policy was implemented or disseminated. Analyzing the later records, there was no reference to actions by the WG on Citizen Security, or by the WG on Justice. The lack of discussion of the actions previously planned and the continuing re-discussion on tasks that can be seen in the transcripts leave no doubt that they did not progress. Furthermore, other simple issues like the organization of the website were not resolved. Several courses promised by Argentina in 2017 did not materialize, which shows a decrease of the country's commitment to take on some tasks before the regional challenges presented under the Mauricio Macri administration.

Among the meetings and seminars in compliance with the action plan of the CSSCJDOT, different themes were congregated, as can be seen in Table 3. The question is whether they will get diffusion in domestic public policies — which may be a relevant topic for researchers on the subject in the near future - or just isolated events without effectiveness for the regional cooperation against crime.

Thereafter, member states reviewed the status of compliance of the Action Plan (2013-2017), in order to put new proposals and initiatives, and to transfer to the next Action Plan those considered priority and which were pending. ${ }^{16}$ The plan so far was not released due to the crisis of UNASUR since 2017 (Vitelli \& Souza, 2018, maio 21).

\footnotetext{
${ }^{15}$ Caracas. Acta. (29 de marzo de 2017). Iv Reunión de ministros del CSSCJDOT de UNASUR.

${ }^{16}$ Caracas. Acta. (28 de marzo de 2017). XI Reunión de la instancia ejecutiva del CSSCJDOT de UNASUR.
} 


\section{Final Remarks: CSSCJDOT as a Sign of the End of UNASUR?}

In the beginning, the CSSCJDOT proved to be full of innovative proposals to solve regional problems in all three areas settled in its objectives: public security, justice and the fight against transnational organized crime. However, after a careful analysis of intentions, decisions and actions of the Council, some challenges can be highlighted.

After monitoring primary documents of the CSSCJDOT in its early years, the conclusion is that it proved ineffective in forming joint policies for the issues of which the Council was responsible. Proposals such as the South American Court for Transnational Organized Crimes, the UNASUR's Network for TOC, the improvement of information sharing, among many others, are clear examples that member states are able to prepare relevant cooperation instances. However, the region suffers from some problems such as the lack of political commitment to regional cooperation, the changes in ideological orientation in a significant number of countries in the region, the excessive belief in normativism and the economic crisis in key countries of the region, like Brazil and Venezuela.

[106] The information sharing faced several challenges, this is suggested in the analysis by member states on the three key themes of CSSCJDOT. One common observation by the states responsible for the collection of information was that few countries were sending the responses for diagnosis, thus often extending the deadlines. Over time, each of the proposed diagnoses were excluded from the agenda, which indicates the problems that the council faces in relation to the traditional discourse of sovereignty in the region (Legler 2013, Ferreira, 2017a), making such initiatives unsuccessful. Something similar happened with the proposals of networks and databases, which were not even initiated until then.

It is important to notice that the difficulties of CSSCJDOT have also been hampered by internal political difficulties of the Member States. Brazil, the country that led the entire process of creating UNASUR, has suffered its worst popularity rate since the re-democratization of the country in 1985. As an example, in June 2018, 3\% of people approved the Temer government and $82 \%$ considered it bad or very bad (Boghossian, 2018, junho 10), opening the way for the rise of the far-right with the election of Jair Bolsonaro. In Venezuela the government of Nicolás Maduro experiences a serious legitimacy crisis 
since the death of Hugo Chávez. Protests against Maduro have faced harsh repression and the arrests of those demonstrators, raising many concerns about human rights. In addition, the economic model of the country gave clear signs of exhaustion under the leadership of Maduro.

Although in the early institutionalization of the CSSCJDOT Argentina attempted to assume a leadership role with strong pro-activity in the working groups, its search for preponderance was barred by the general crisis of UNASUR since 2017. During the creation of UNASUR, the region experienced a wave of declared left-wing governments, which facilitated the creation of the organization and its autonomous orientation in opposition to the United States. However, this context no longer exists, as can be clearly seen in the cases of Brazil and Argentina, which under Jair Bolsonaro and Mauricio Macri have recently shifted toward an ideological profile contrary to that of the previous governments of Dilma Rousseff and Cristina Fernández. These governments do not support the fight against neoliberalism nor the autonomy from the United States, premises that grounded the organization (Sanahuja 2012). This makes difficult the participation of these countries in UNASUR as in the initial years of the organization.

The tradition of normativism in the region is also transparent in the council. The creation of the CSSCJDOT itself, the statute, the timetable and the action plan were made with fairly progressive views, encouraging popular participation, respect for human rights, immigrants, indigenous peoples, race and gender issues. However, the obstacles in advancing these issues also prove that simply introducing a debate scenario and setting an agenda is not enough to solve these problems. Without the active participation of the states to materialize this agenda, the council results ineffective. Well-designed statutes and rules are nothing without actions and commitment with regional cooperation.

The only actions that advanced in the council were the organization of regional events. All of them had the objective of sharing information on successes in their areas, through several panels in the charge of the member countries. It is impossible to accurately determine their impact of such events on regional policies. However, it can be said that a simple exposition of experiences with no clear objective of forming unified policies makes the possibility of diffusion policies quite low. 
The next years will show us whether the current scenario for UNASUR means its complete decline or just a severe a crisis. Regardless of these two possibilities, the fact is that the region has already lost precious time to put into practice its innovative initial premises and to weaken, through regional cooperation, the curse of the violence that affects thousands of South Americans daily.

\section{References}

1. Banfield, Jessie. (2014). Crime and Conflict: The New Challenge for Peacebuilding. London: International Alert.

2. Boghossian, Bruno. (2018, junho 10). Reprovação aumenta e torna Temer o presidente mais impopular da história. Folha de São Paulo. Retrieved from https://goo. $\mathrm{gl} / \mathrm{f} 4 \mathrm{zEzc}$

3. Brasil. Congresso. Câmara dos Deputados. Lei 12595. (19 de janeiro de 2012). Lei Orçamentária Anual. Brasília, D. F.

4. Brasil. Congresso. Câmara dos Deputados. Lei 12952. (20 de janeiro de 2014). Lei Orçamentária Anual. Brasília, D. F.

5. Brasil. Congresso. Câmara dos Deputados. Lei 13255. (14 de janeiro de 2016). Lei Orçamentária Anual. Brasília, D. F.

6. Cepik, Marco \& Borba, Pedro. (2011). Crime organizado, estado e segurança internacional. Contexto Internacional, 33 (2), pp. 375-405. https://doi.org/10.1590/ S0102-85292011000200005

7. Cerqueira, Daniel et al. (2017). Atlas da Violência 2017. Rio de Janeiro: Instituto de Pesquisa Econômica Aplicada.

8. Ferreira, Marcos Alan S. V. (2017a). Criminality and Violence in South America: The Challenges for Peace and UNASUR's Response. International Studies Perspectives, 18 (1), pp. 64-80. https://doi.org/10.1093/isp/ekw008

9. Ferreira, Marcos Alan S. V. (2017b). Estudos Críticos da Paz e Crime Organizado Transnacional. Revista Crítica de Ciências Sociais, 113, p. 29-50. https:// doi.org/10.4000/rccs.6643

10. Ferreira, Marcos Alan S. V. (2018, junho 20). A crise da UNASUL como promotora da paz regional. Mundorama. Retrieved from https://www.mundorama. net $/ ? \mathrm{p}=24677$

11. Framento, Rodrigo \& Ferreira, Marcos Alan S. V. (2018). UNASUL e a promoção da paz social: a institucionalização do Conselho de Segurança Cidadã, Justiça e ações contra o Crime Organizado Transnacional. Revista de Iniciação Científica em Relações Internacionais, 5 (10), pp. 134-168.

12. Galtung, Johan. (1969). Violence, Peace, and Peace Research. Journal of Peace Research, 6 (3), pp. 167-191. https://doi.org/10.1177/002234336900600301 
Violence and Justice in UNASUR's Institutional History. From the Early Optimism...

13. Galtung, Johan. (1990). Cultural Violence. Journal of Peace Research, 27 (3), pp. 291-305. https://doi.org/10.1177/0022343390027003005

14. Holsti, Kalevi. (1996). The State, War and the State of War. Cambridge: Cambridge University. https://doi.org/10.1017/CBO9780511628306

15. Imbusch, Peter; Misse, Michel \& Carrión, Fernando. (2011). Violence Research in Latin America and the Caribbean: A Literature Review. International Journal of Conflict and Violence, 5 (1), pp. 87-154.

16. Kacowicz, Arie. (1998). Zones of Peace in the Third World: South America and West Africa in Comparative Perspective. Albany: State University of New York.

17. Kim, Rakhyun. (2016). The Nexus between International Law and the Sustainable Development Goals. Review of European Comparative \& International Environmental Law, 25 (1), pp. 15-26. https://doi.org/10.1111/reel.12148

18. Legler, Thomas. (2013). Post-Hegemonic Regionalism and Sovereignty in Latin America: Optimists, Skeptics, and an Emerging Research Agenda. Contexto Internacional. 35 (2), pp. 325-352. https://doi.org/10.1590/S010285292013000200001

19. Lyra, Mariana Preta Oliveira de. (2014). O processo de desecuritização do narcotráfico na UNASUL. (Master's Dissertation in International Relations). Universidade Estadual da Paraíba, João Pessoa.

20. Malamud, Andrés. (2017). Foreign Policy Retreat: Domestic and Systemic Causes of Brazil's International Rollback. Rising Powers Quarterly, 2 (2), pp. 149-168.

21. Ministério da Justiça e Segurança Pública. (2010). Carta do I Encontro Nacional da Rede de Enfrentamento ao Tráfico de Pessoas. Retrieved from http://www. justica.gov.br/sua-protecao/trafico-de-pessoas/politica-brasileira/anexos/2010carta belohorizonte-1.pdf

22. Ministerio de Seguridad. (2014, agosto 22). Rodríguez encabezó seminario de UNASUR. Argentina.gob.ar. Retrieved from https://www.argentina.gob.ar/noticias/ grodr\%C3\%ADguez-encabez\%C3\%B3-seminario-de-unasur

23. Ministerio de Seguridad. (2015, abril 27). Taller regional para la prevención y el accionar integral contra la Trata de Personas. Argentina.gob.ar. Retrieved from https://www.argentina.gob.ar/noticias/gtaller-regional-para-la-prevenci\%C3\%B3n-yel-accionar-integral-contra-la-trata-de-personas

24. Oliveira, Gilberto Carvalho. (2017). Estudos da Paz: origens, desenvolvimentos e desafios críticos atuais. Carta Internacional, 12 (1), pp. 148-172. https://doi. org/10.21530/ci.v12n1.2017.611

25. Sanahuja, José Antonio. (2012). Regionalismo post-liberal y multilateralismo en Sudamérica: El caso de UNASUR. In: Serbin, Andrés; Martínez, Laneydi \& Ramanzini Júnior, Haroldo (orgs.). El regionalismo "post-liberal" en América Latina y el Caribe: Nuevos actores, nuevos temas, nuevos desafíos (pp. 19-71). Buenos Aires: Cries. 
26. Seguridad, Justicia y Paz. (2017). Metodología del ranking (2016) de las 50 ciudades más violentas del mundo. Retrieved from http://www.seguridadjusticiaypaz. org.mx/biblioteca/summary/6-prensa/239-las-50-ciudades-mas-violentas-del-mundo2016-metodologia

27. Terra. (2012, maio 4). Unasul quer unidade independente contra crime organizado. Retrieved from http://noticias.terra.com.br/mundo/america-latina/unasulquer-unidade-independente-contra-crime-organizado,24b99c01358da310VgnCLD2 00000bbcceb0aRCRD.html

28. UNASUR. (n.d). Archivo Digital de UNASUR. Retrieved form http://docs. unasursg.org

29. Villa, Rafael D. \& Pimenta, Marília C. S. (2016). A longa paz na América do Sul: questionamentos às teses da paz negativa na região. Papel Político, 21 (2), pp.435-468. https://doi.org/10.11144/Javeriana.papo21-2.Ipas

30. Vitelli, Marina \& Souza, Tamires. (2018, maio 21). Suspensão da participação na UNASUL: reflexos sobre a Segurança e a Defesa regional. ERIN GEDES. Retrieved from http://www.eris-gedes.org/single-post/suspensao-da-pariticiacao-na-UNASUL

31. Werner, Guilherme Cunha. (2009). O crime organizado transnacional e as redes criminosas: presença e influência nas Relações Internacionais contemporâneas. (Ph.D. Thesis in Political Science). Universidade de São Paulo, São Paulo.

32. Zabyelina, Yuliya. (2009). Transnational Organized Crime in International Relations. Central European Journal of International and Security Studies, 3 (1),

[110] pp. 11-22. 